\title{
Kreft og lindrende behandling i Mongolia
}

\author{
På tross av et vanskelig utgangspunkt er endringsprosesser i gang i helsetjenesten i Mongolia. I april 2011 \\ fikk jeg studere etablering av lindrende behandling til kreftpasienter på nært hold. Mitt inntrykk er at tilgang \\ til morfin og vektlegging av kommunikasjon har gitt kreftpasienter i livets sluttfase betydelig bedre livs- \\ kvalitet. Samarbeid mellom myndighetene, det nasjonale fagmiljøet og internasjonale bistandsaktører er \\ avgjørende.
}

Engelsk oversettelse på www.tidsskriftet.no

\author{
Målfrid Holmaas Bjørgaas \\ malfrid.bjorgaas@lyse.net \\ Mobilt palliativt team \\ Stavanger universitetssjukehus \\ og \\ Håbet Helsehus
}

Mongolia var sterkt bundet til Sovjetunionen frem til 1990. De siste 20 årene har vært preget av postkommunistisk krise og korrupsjon, men også av nyorientering og åpning mot det internasjonale samfunn. Befolkningen er estimert til tre millioner (1). Omtrent en million bor i hovedstaden Ulan Bator. Resten lever på steppene, de fleste som nomader.

Helsevesenet ble bygd opp av russerne. Kommunistene var gode på struktur. Bygninger og ansatte finnes, men kvaliteten på helsehjelpen synes fortsatt å være svært mangelfull (2). Tabell 1 viser noen helseindikatorer, sammenholdt med tilsvarende tall fra Norge (3).

\section{Min bakgrunn}

I perioden 2005-07 jobbet jeg i Mongolia for Norsk Luthersk Misjonssamband (4). Flere tidligere bistandsprosjekter var da under utfasing, og en hovedoppgave ble planlegging av nye prosjekter innen primærhelsetjeneste. I samarbeid med nasjonale og regionale helsemyndigheter ble tre provinser i vestregionen valgt som prosjektområde for Strengthening Primary Health Care Project $(5,6)$. Prosjektet har fasilitert kurs om kreft og palliasjon sammen med mange andre allmennmedisinske temaer fra 2008 til dags dato.

I april 2011 besøkte jeg Mongolia på ny, i forbindelse med overlegepermisjon fra Mobilt palliativt team. I denne teksten vil jeg formidle noen av de inntrykk jeg sitter igjen med etter samtaler med kontakter i nasjonal og lokal helseadministrasjon og med primærleger i provinsen Khovd, som deltok på kurs i regi av prosjektet.

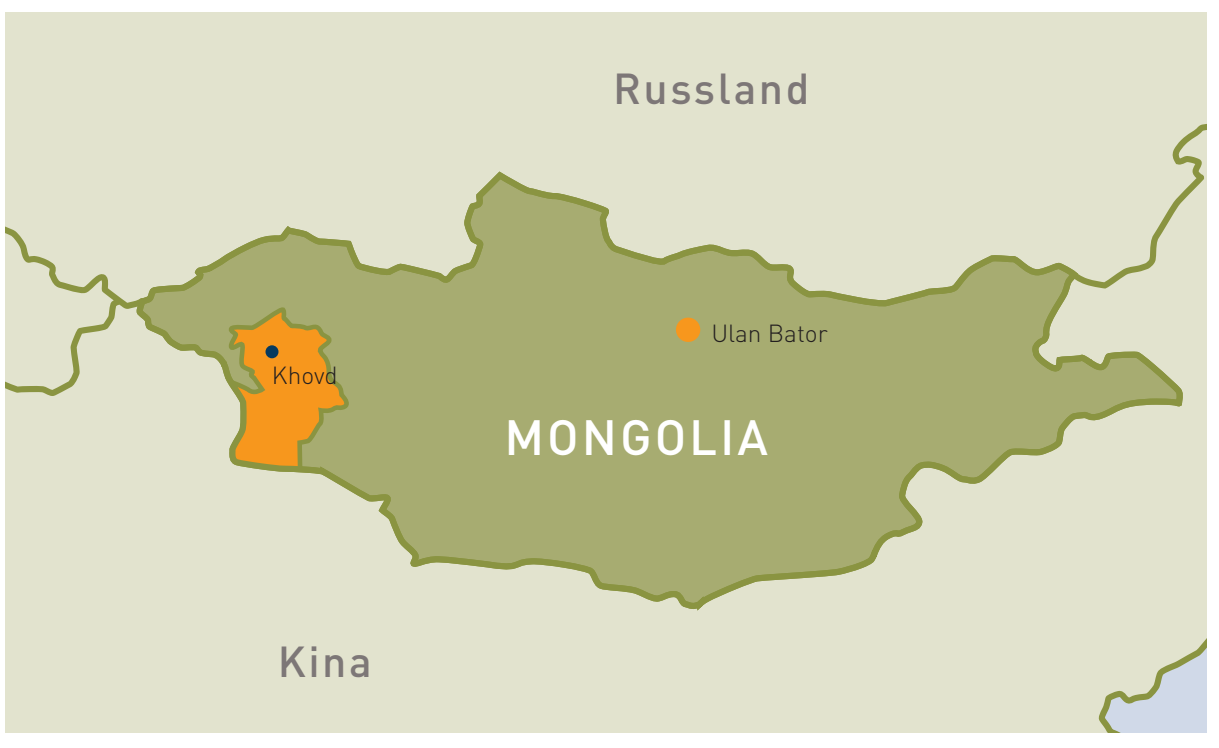

\section{Sen diagnose}

I 2005 ble over $80 \%$ av kreftpasientene diagnostisert i stadium 3 og stadium 4 (7). Tabell 2 viser fordelingen av de tre vanligste kreftformene (7). Den høye forekomsten av primær leverkreft antas å skyldes endemisk hepatitt B og hepatitt C samt dårlig kosthold og høyt alkoholforbruk (7). Egne observasjoner av diagnostiske muligheter og rapporteringsrutiner tilsier at mange tilfeller av levermetastaser uten erkjent primærtumor sikkert også har havnet $\mathrm{i}$ denne gruppen.

Det nasjonale kreftsenteret i Ulan Bator er ansvarlig for diagnostikk og behandling. Endoskopi er i praksis ikke tilgjengelig, heller ikke mammografi, stort sett er det bare røntgenundersøkelse man kan tilby. Ultralydundersøkelse brukes mye, men mitt inntrykk er at indikasjoner og tolking ofte

Tabell 1 Indikatorer for Mongolia og Norge, basert på tall fra WHO, 2009 (3)

Indikatorer

Andel av befolkning < 15 år (\%)

Andel av befolkning $>60$ år $(\%)$

Forventet levealder (år)

Spedbarnsdødelighet < 1 år per 1000 levendefødte 1

Dødsrisiko for alderen 15-60 år/1 000 innbyggere

Offentlig forbruk til helse/innbygger (USD)

1 Tall fra 2010 


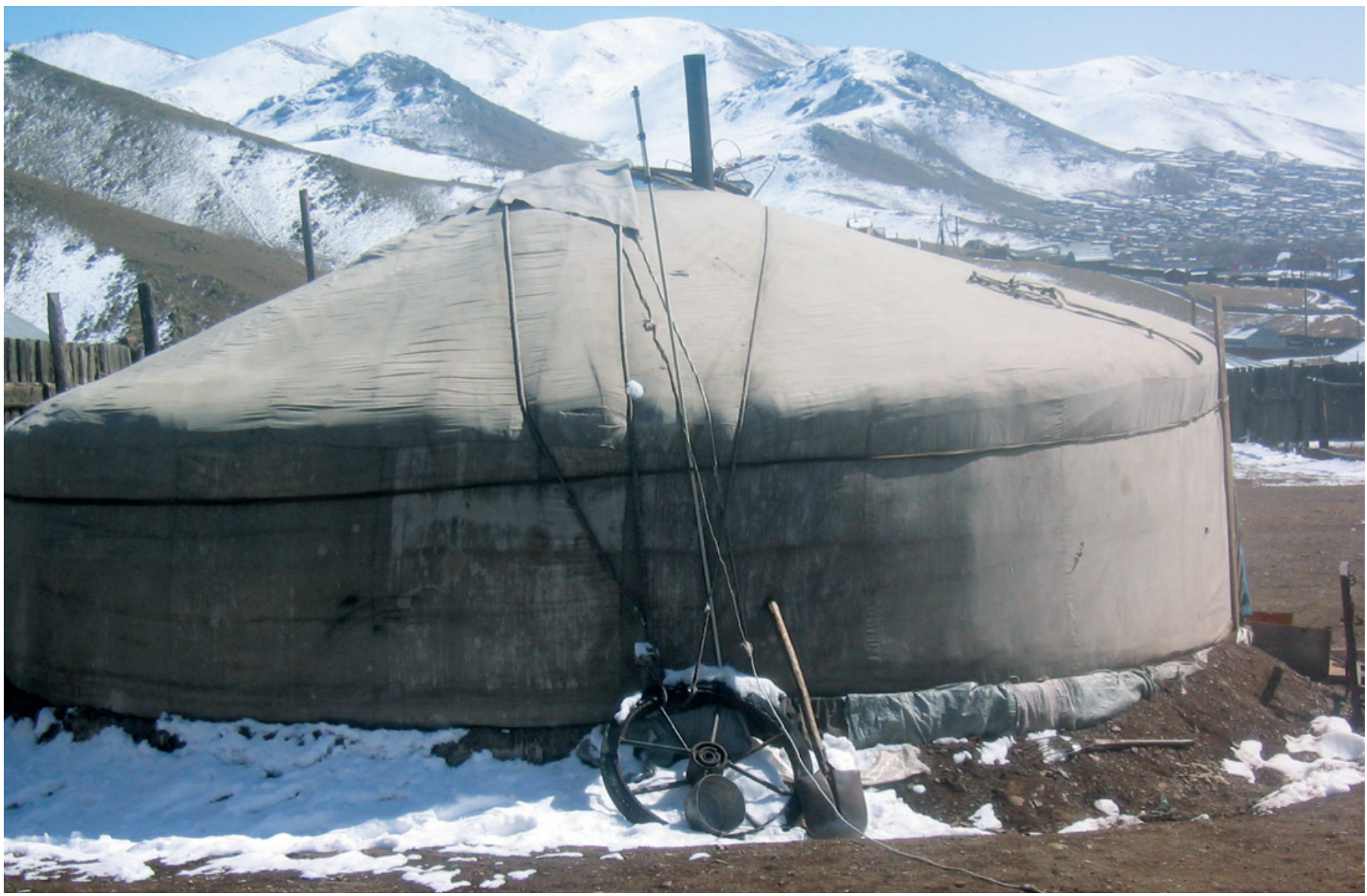

Ger (mongolsk: hjem), et tradisjonelt mongolsk familietelt. Foto Målfrid Holmaas Bjørgaas

er mer preget av magisk enn av medisinsk tankegang. Det finnes ingen screeningprogrammer. Laboratoriekapasiteten er dårlig, og kunnskapen om symptomer og risiko er liten $\mathrm{i}$ befolkningen (7).

Behandlingstilbudet på regions- og fylkesnivå er dårlig eller fraværende. Kreftkirurgi finnes i praksis ikke utenfor hovedstaden, og også der er tilbudet sterkt begrenset. De som har ressurser til det, drar til utlandet. Ifølge kreftplanen er behandlingsindikasjonene ved det nasjonale kreftsenteret tilfeldige og kvaliteten på behandlingen lav. På grunn av pengemangel er det nesten ingen barn som får kjemoterapi (7).

\section{Lindrende behandling}

Naturlig nok vil alle pasienter raskt trenge palliativ behandling under slike forhold. Sju av ti dør innen ett år etter diagnosen (7).

Dr. Oduntuya Davaasuren har oversatt retningslinjer og lærestoff til mongolsk og er ansvarlig for palliasjon både i medisinerutdanningen og i videreutdanning for helsepersonell. Hun er en ildsjel som har bidratt betydelig til at politiske vedtak, planverk og forskrifter er kommet på plass (8). Fra 2003 fikk primærlegene lov til å forskrive morfin. Morfin er i prinsippet gratis for dem som trenger palliativ behandling, men budsjettene strekker ikke til og leveransene er fortsatt ustabile. Jeg ble fortalt at peroral morfin ikke var tilgjengelig $i$ det hele tatt $i$ fire måneder i 2010 på grunn av importstopp. Etter det økte prisene. Fem tabletter $10 \mathrm{mg}$ hurtigvirkende morfin koster nå ca. 1 amerikansk dollar. Til sammenlikning tjener en familie kanskje 50-80 dollar per måned.

Primærleger i Khovd fortalte meg at paracetamol og ikke-steroide antiinflammatoriske midler stort sett er tilgjengelig lokalt. Tilgangen på morfin er blitt bedre de siste årene, men ifølge legene er individuelt tilpasset smertebehandling vanskelig pga. et utilstrekkelig utvalg av administrasjonsformer og ujevne leveranser. Vekt på opplæring ser imidlertid ut til å ha gitt legene større trygghet og frimodighet i forskrivningen.

\section{Videre utfordringer}

Kreftplanen skisserer fire pilarer for forbedring: forebygging, tidlig diagnostikk, kurasjon og palliasjon (7).

\section{Forebygging}

Nesten en tredel av den voksne befolkningen røykte i 2002, ti ganger flere menn enn kvinner (7). Alkoholforbruket er stort, men sikre tall mangler. Innholdet av tungmetaller fra gruvedrift er økende i grunnvannet og jordsmonnet (7). Hepatitt B-vaksinasjon av nyfødte er i stor grad gjennomført (7).
Forskning predikerer at vaksinering mot humant papillomvirus (HPV) kan redusere forekomsten av livmorhalskreft med inntil tre firedeler (9). Visjonært nok nevnes HPV-vaksinasjon av alle jenter som et fremtidsmål i kreftplanen, men foreløpig er det helt urealistisk, både økonomisk og organisatorisk (7).

\section{Tidlig diagnostikk og kurasjon}

Uten behandlingsmuligheter er tidlig diagnostikk meningsløst. Det arbeides med behandlingsindikasjoner og standardiserte behandlingsløp. Opplæring i enkle kirurgiske metoder kan være effektivt (10).

Tabell 2 De tre vanligste kreftformene for henholdsvis menn og kvinner i Mongolia (7)

\begin{tabular}{|c|c|}
\hline & Prosent \\
\hline \multicolumn{2}{|l|}{ Menn } \\
\hline Lever & 39 \\
\hline Magesekk & 19 \\
\hline Lunger & 13 \\
\hline \multicolumn{2}{|l|}{ Kvinner } \\
\hline Lever & 30 \\
\hline Livmorhals & 17 \\
\hline Magesekk & 11 \\
\hline
\end{tabular}


Videreutvikling av kjemoterapi og strålebehandling er dyrt og krever spesialisert kompetanse og penger utenfra. Økt kunnskap i befolkningen om varselssymptomer og hensiktsmessig helseatferd er viktig (11). Opplæringsprogrammer i samarbeid med internasjonale partnere er i gang. Strengthening Primary Health Care Project er ett eksempel.

Palliasjon

I palliasjonsplanen vektlegges utbygging av hjemmebaserte tjenester og tverrfaglige team som kan bistå lokalt $(7,8)$. Ingen av delene er realisert. Foreløpig finnes det én palliativ post ved det nasjonale kreftsenteret, med 15 senger, men min erfaring var at samhandling med primærhelsetjenesten mangler.

Kommunikasjon og pasientinformasjon diskuteres i fagmiljøet, men tradisjonelt snakkes det lite om døden og helst ikke direkte med den syke. Kursdeltakere i Khovd mente at pasientene bør få informasjon, men at de pårørende ofte ikke ønsker dette. Likevel formidlet legene erfaringer om at åpenhet er bedre enn taushet. De fortalte om muligheter som åpnet seg fordi de syke kunne få ordnet i tide noe som var viktig for dem eller få fremskyndet en familiebegivenhet. Jeg tror at når gode fortellinger spres, vil endringer komme etter hvert. Helsepersonell trenger møtepunkter for dialog. Kursene er slike møtepunkter.

\section{Suksessfaktorer}

Tilgang til morfin er en stor forbedring av mongolske kreftpasienters situasjon. Faglig kompetente ildsjeler med god kontakter i det nasjonale helsepolitiske miljø er avgjørende for at endring kan skje. Politiske vedtak og planer må på plass. Lokal administrativ og helsefaglig ledelse må inn i prosessene så tidlig at de får forståelse for endringsbehovet i forkant av konkrete tiltak. Det muliggjør eierskap til de tiltakene som senere settes i gang (12).

Økonomisk og faglig bistand utenfra må gå i takt med lokal styring og motivasjon. Tilrettelegging for dialog mellom alle involverte er nødvendig. Lindrende behandling i Mongolia er ett eksempel på at relativt beskjeden tilførsel av ressurser kan føre til endring.

\section{Målfrid Holmaas Bjørgaas (f. 1963)}

er spesialist i allmennmedisin og fastlege i Sandnes. Hun har i tillegg en bistilling som overlege ved Mobilt palliativt team ved Stavanger universitetssjukehus. I årene 2005-07 arbeidet hun som prosjektkonsulent i Mongolia for Norsk Luthersk Misjonssamband, med bosted Ulan Bator.

Forfatter har fylt ut ICMJE-skjemaet og oppgir ingen interessekonflikter.
Litteratur

1. Wikipedia. Mongolia. http://no.wikipedia.org/wiki/ Mongolia (6.11.2011)

2. Olsen B, Seim A, Shetelig AW. Landet der himmelen alltid er blå? Tidsskr Nor Lægeforen 2002; 122 $95-7$

3. WHO. Global Health Observatory Data Repository Country statistics. http://apps.who.int/ghodata/ ?vid $=13900 \&$ theme $=$ country $(3.1 .2012)$

4. Norsk Luthersk Misjonssamband. Prosjektkatalogen. Mongolia. http://www.nlm.no/nlm/stoett-oss/ prosjektkatalogen/mongolia (3.1.2012)

5. Digni. Prosjekter. http://www.digni.no/newsread/ frame aspx?nodeid=5180 (30.12.2011)

6. Norwegian Lutheran Mission Mongolia. Project document Strengthening Primary Health Care Project, 2008-2013. Ulan Bator: Norwegian Lutheran Mission Mongolia, 2007

7. Ministry of Health, National Cancer Center, WHO Western Pacific Region. National Cancer Control Program 2007-2017 Mongolia. Ulan Bator: Ministry of Health, 2009.

8. Davaasuren O Stjernswärd J Callaway $\mathrm{M}$ et al. Mongolia: establishing a national palliative program. Pain Symptom Manage 2007; 33: 568-72

9. Shi JF, Qiao YL, Smith JS et al. Epidemiology and prevention of human papillomavirus and cervical cancer in China and Mongolia. Vaccine 2008; 26 (suppl 12): M53-9.

10. Elit LM, Rosen B, Jimenez W et al. Teaching cervical cancer surgery in low- or middle-resource countries. Int J Gynecol Cancer 2010; 20: 1604-8.

11. Yoo KY. Cancer prevention in the Asia Pacific region. Asian Pac J Cancer Prev 2010; 11: 839-44 12. O'Rourke M, Hindle D, Dungu Y et al. Community involvement in health in Mongolia. Aust Health Rev 2003; 26: 124-9.

Mottatt 11.9. 2011, første revisjon innsendt 7.11. 2011, godkjent 5.1. 2012. Medisinsk redaktør Siri Lunde. 